\title{
Tanggungan Nafkah Suami yang Digantikan Istri menurut Ulama Pedesaan
}

\author{
Madiha Dzakiyyah Chairunnisa \\ Fakultas Hukum, Universitas Terbuka (UT) \\ Email: madihadzakiyahch@gmail.com \\ Icep Baban Abdul Wahab \\ Institut Agama Islam Darussalam (IAID) Ciamis, Jawa Barat \\ Lilis Nurasiah Jamil \\ Institut Agama Islam Darussalam (IAID) Ciamis, Jawa Barat
}

\begin{abstract}
ABSTRAK
Menjalankan kehidupan berumah tangga, tentunya antara suami dan istri memiliki hak dan kewajiban masing-masing yang harus ditunaikan. Kewajiban suami adalah memberikan mahar dan nafkah kepada istri, sedangkan kewajiban istri yang merupakan hak suami adalah seorang istri harus patuh dan taat kepada suami. Selain itu istri juga wajib memenuhi segala kebutuhan suami, baik itu kebutuhan rohaniah maupun bathiniah. Akan tetapi di kalangan masyarakat banyak terjadi permasalahan peran seolah ditukar, yaitu istri yang menafkahi suami dengan alasan suami yang sudah tidak mampu lagi bekerja dikarenakan sakit, juga karena suami yang enggan untuk bekerja. Realita tersebut banyak terjadi di kalangan masyarakat Desa Sindangjaya. Hal ini menarik perhatian peneliti untuk mengetahui lebih jauh, bagaimana pendapat ulama Desa Sindangjaya terhadap pemberian nafkah istri kepada suami.
\end{abstract}

\section{ABSTRACT}

Running married life, of course between husband and wife have rights and obligations of each that must be fulfilled. The duty of the husband is to give dowries and livelihood to the wife, while the obligation of the wife who is the husband's right is a wife must obey and obey the husband. In addition, the wife is also required to meet all the needs of the husband, both spiritual and spiritual needs. However, among the community there are many problems of role as if exchanged, the wife who feeds the husband with the reasons husband is no longer able to work due to illness, also because the husband is reluctant to work. Reality is much happening among the people of Sindangjaya Village. This attracted the attention of researchers to find out more, how the opinion of the village cleric Sindangjaya towards providing a living wife to husband. 
Keywords: Village Ulama's opinion, livelihood

\section{PENDAHULUAN}

Manusia mempunyai naluri (kecenderungan) merasa terpikat kepada lawan jenisnya. Untuk merespon naluri tersebut Islam melembagakan pernikahan. Istilah ini berasal dari akar kata kerja نكح yang mengandung tiga pengertian. Pertama, menurut bahasa nikah berarti bersetubuh atau berkumpul. Kedua, menurut ahli usul, terdapat tiga pendapat tentang pengertian nikah. Menurut ahli usul Hanafiah, menurut aslinya nikah berarti setubuh, dan secara majazi ialah akad yang menghalalkan hubungan biologis antara pria dan wanita. Menurut ahli usul Syafi'iah, nikah menurut aslinya ialah akad yang menghalalkan hubungan kelamin antara pria dan wanita, sedang secara majazi, berarti bersetubuh. Sedangkan menurut pendapat ketiga, nikah mengandung kedua arti tersebut, sebagai akad dan setubuh. Ketiga, menurut ahli figh, ada beberapa definisi nikah namun nikah pada hakikatnya adalah akad yang diatur oleh syara' untuk memberikan kepada pria hak memiliki dan menikmati seluruh tubuh wanita itu serta untuk membentuk rumah tangga. (Laa Jamaa dan Hadidjah, 2008: 103)

Dengan demikian pernikahan merupakan ikatan yang luhur yang dijalin oleh manusia yang berlainan jenis kelamin, karakter dan keinginan. Keluhuran ikatan pernikahan itu dilukiskan oleh Allah SWT dengan ungkapan misaqan ghaliza ( suatu ikatan janji yang kokoh) seperti terungkap dalam QS. An-Nisa: 21

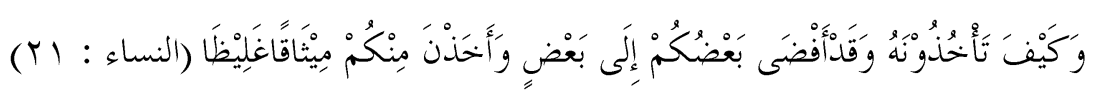

Bagaimana kamu akan mengambilnya kembali, padahal sebagian kamu telah bergaul (bercampur) dengan yang lain sebagai suami istri. Dan mereka (istri-istrimu) telah mengambil dari kamu perjanjian yang kuat. (Q.S. An-Nisa, 4: 21)

Pernikahan mempunyai akibat hukum yang mengikat berupa hak dan kewajiban, baik yang ditunjukkan kepada suami, istri maupun bagi kedua belah pihak. Kewajiban suami terhadap istri pada dasarnya merupakan hak bagi istri dan begitu pula sebaliknya. Kewajiban istri terhadap suami merupakan hak suami. (La Jamaa dan Hadidjah, 2008: 105)

Sebagai seorang pemimpin dalam keluarga, suami memiliki kewajiban untuk memberikan nafkah kepada istri dan anak-anaknya baik berupa nafkah lahir maupun nafkah batin. Jenis nafkah yang wajib, yaitu segala sesuatu yang dibutuhkan oleh sang istri serta keluarganya, sebagaimana dikatakan oleh Ibnu Qudamah. Termasuk kategori nafkah 
wajib ini meliputi kebutuhan primer, seperti makanan, minuman, pakaian, tempat tinggal, perhiasan serta sarana-sarana dan peralatan yang dibutuhkan istri untuk memenuhi kebutuhan primernya juga pemenuhan kebutuhan primernya. Semua itu wajib dipenuhi oleh suami.

Tempat tinggal atau rumah merupakan kebutuhan primer suami istri di samping makanan dan pakaian. Keberadaan rumah dan tempat tinggal juga berpengaruh terhadap pertumbuhan anak. Keberadaan rumah sebagai tempat tinggal akan mempengaruhi terbentuknya rumah tangga yang bahagia, anak-anak dapat tumbuh dan berkembang secara baik dan berkualitas. (La Jamaa dan Hadidjah, 2008 : 112)

Kehidupan rumah tangga yang bahagia sulit diwujudkan jika sandang, pangan yang bergizi dan papan (tempat tinggal) tidak dapat dipenuhi. Jika suami tidak memberi nafkah kepada istri dan atau anaknya, maka istri dibolehkan mengambil sendiri tanpa sepengetahuan suaminya. (KH. Ibrahim Husen, Konsepsi Pembentukan Keluarga Bahagia dalam Islam: 38-39).

Hal ini menunjukkan, bahwa hukum Islam memberikan perhatian serius terhadap kekerasan ekonomi (penelantaran rumah tangga). Dalam kaitan ini Imam Malik berpendapat, bahwa apabila seorang istri mengeluh terhadap suaminya karena ia bersikap nusyuz dan menjauhi istri, maka istri boleh saja mengajukan perkara itu kepada pihak pengadilan, lalu pihak pengadilan berwenang memberikan nasehat kepada suami itu. Jika nasehat itu tidak dihiraukannya, maka pihak pengadilan berkewajiban menyuruh dia memberikan nafkah kepada istri dan melarang istri taat dan patuh kepadanya. Jika cara ini tidak mengubah sikap suami, maka pengadilan boleh memberikan sanksi kepada suami itu dengan cara memukul dengan tongkat. (Muhammad Rasyid Uwayyid, 2003: 11-12)

Namun, perempuan di Indonesia pada saat ini mempunyai peran yang cukup seimbang dengan laki-laki (suami). Hal ini dapat dilihat dari kontribusi ekonomi yang diberikan oleh istri di dalam keluarganya. Fenomena istri yang bekerja menjadi hal biasa, namun hal ini menjadi polemik bagi kaum agamawan, mereka mengaitkan perempuan bekerja dengan gerakan feminisme, namun pada sebagian keluarga menengah ke bawah bekerja merupakan suatu keharusan untuk bertahan hidup dan mencukupi kebutuhan keluarga. Oleh karena itu, fenomena perempuan bekerja pada keluarga menengah ke atas, dikaitkan dengan kesetaraan gender. Sedangkan pada keluarga menengah ke bawah terjadi karena untuk keberlangsungan hidup dan masa depan anak-anaknya.

Tidak sedikit para istri yang bekerja untuk menghidupi keluarganya. Di samping untuk mencukupi kebutuhan sehari-hari, mereka (istri) juga bekerja untuk menggantikan peran suami sebagai pencari nafkah. Hal ini 
disebabkan oleh beberapa faktor pendukung, antara lain karena kurang terpenuhinya kebutuhan keluarga jika hanya mengandalkan pendapatan dari suami. Selain itu juga karena suami yang sudah tidak memiliki kemampuan lagi untuk mencari nafkah, sehingga istri yang harus bekerja. Di samping itu juga karena suami yang tidak mau bekerja, sehingga istrilah yang berperan sebagai pencari nafkah.

Permasalahan tersebut di atas menjadi bahan perbincangan di kalangan masyarakat. Bagaimana bisa seorang istri yang bertanggungjawab untuk menafkahi dan menghidupi kebutuhan keluarga. Hal ini sangat penting sekali untuk diperbincangkan, bagaimana pendapat masyarakat tentang fenomena istri yang menafkahi keluarga, termasuk menurut para ulama.

\section{LANDASAN TEORI}

Konsep Nafkah

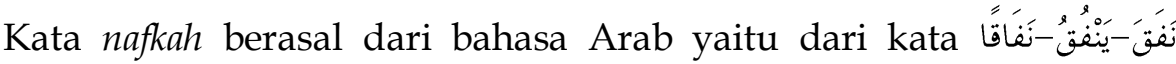
بَفَقَة -نَفَقَات yang artinya nafkah, atau barang-barang yang dibelanjakan seperti uang. (Mahmud Yunus, Kamus Bahasa Arab Indonesia, 2010: 465). Dalam Kamus Besar Bahasa Indonesia diartikan bahwa nafkah yaitu belanja untuk hidup, (uang) pendapatan yang diberikan kepada istri untuk bekal hidup seharihari. (Departemen Pendidikan Nasional, Kamus Besar Bahasa Indonesia Edisi Ketiga, 2001: 770).

Menurut istilah nafkah merupakan pemberian seseorang kepada orang lain sesuai dengan perintah Allah SWT seperti terhadap istri, orang tua, kerabat, dan sebagainya. Nafkah merupakan hak istri atas suami atau kewajiban seorang suami atas istrinya. Dari definisi ini nafkah adalah suatu peran ekonomis dalam keluarga atau orang-orang yang terikat dalam suatu akad nikah dan konsekuensi hubungannya. (Amir Syarifuddin, 2006: 80)

Keberadaan hukum nafkah adalah sebagai akibat dari adanya sebuah beban tanggungjawab. Hukum nafkah memiliki tingkatan-tingkatan besaran kewajiban menyesuaikan kemampuan suami untuk memenuhi kebutuhan istri. Kebutuhan istri yang dimaksud berupa makanan, tempat tinggal, pelayanan, dan pengobatan meskipun istri berkecukupan. (Sayyid Sabiq, 2008: 427)

Dari beberapa pengertian nafkah tersebut dengan beberapa karakteristiknya, maka nafkah dapat dirumuskan dalam pengertian kewajiban seseorang yang timbul sebagai akibat perbuatannya yang mengandung beban tanggungjawab, berupa pembayaran sejumlah biaya guna memenuhi kebutuhan baik pokok ataupun sekunder terhadap sesuatu 
yang berada dalam tanggungannya itu. Adapun jumlah nafkah yang berhak diterima istri tidak ada ketetapan yang pasti. Jumlah (kadar) sandang dan pangan yang wajib ditunaikan suami disesuaikan dengan kemampuan suami. (Khoirudin Nasution, 2004: 181)

Menurut Sulaiman Rasjid dalam Fiqih Islam ada tiga sebab yang mewajibkan nafkah, yaitu:

a. Sebab Kerabat (Qarabah)

Bapak atau Ibu wajib memberi nafkah kepada anaknya, begitu juga kepada cucu, jika dia tidak mempunyai Bapak. Abu Sufyan telah mengadukan masalahnya kepada Rasulullah SAW. Dia berkata, "Abu Sufyan seorang yang kikir, dia tidak memberi saya dan anak saya nafkah selain yang saya ambil dengan tidak diketahuinya. Apakah yang demikian itu memadharatkan saya?" jawab beliau:

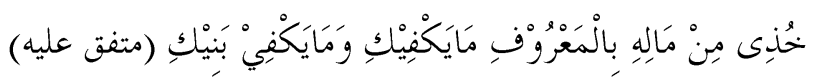

Ambillah olehmu dari hartanya dengan baik, sekadar untuk mencukupi keperluanmu dan anakmu. (Sepakat Ahli Hadits) (Fiqih Sunnah, 2008: 422)

Syarat wajibnya nafkah atas kedua ibu bapak kepada anak ialah apabila si anak masih kecil dan miskin, atau sudah besar tetapi tidak kuat berusaha dan miskin pula. Begitu pula sebaliknya, anak wajib memberi nafkah kepada kedua ibu bapaknya apabila keduanya tidak kuat lagi berusaha dan tidak mempunyai harta.

Dalam hubungan ini, para fuqaha memiliki perbedaan pendapat. Kalangan Malikiyah menilai qarabah yang wajib nafkah hanya pada hubungan orang tua dan anak (walid wa al-walad). Kalangan Syafi'iyah, menilai qarabah dalam hubungan orang tua dan anak, dan hubungan cucu dan kakek (usul dan furu'). Hanafiyah menilai qarabah dalam konteks mahramiyah tidak terbatas usul dan furu', sehingga meliputi kerabat ke samping (hawasyiy), dan dzawil arham. Hanabilah, memahami qarabah dalam konteks hubungan waris fard dan 'asabah, meliputi usul, furu', hawasyiy, dan dzawil arham yang berada pada jalur nasab. (Wahbah Al-Zuhailiy, Al-Figh alIslamiy wa adillatuhu : 83-84)

b. Sebab Penikahan (Zawjiyyah)

Suami diwajibkan memberi nafkah kepada istrinya yang taat, baik makanan, pakaian, tempat tinggal, perkakas rumah tangga dan lain-lain menurut keadaan di tempatnya masing-masing dan menurut kemampuan suami. Banyaknya nafkah adalah menurut kebutuhan dan kebiasaan yang berlaku di tempat masing-masing, disesuaikan dengan tingkatan dan keadaan suami. (Sulaiman Rasyid, Fiqih Islam, 2008: 422) 
Walaupun sebagian ulama mengatakan bahwa nafkah istri itu ditetapkan dengan kadar yang tertentu, tetapi yang mu'tamad tidak ditentukan, hanya sekadar cukup serta disesuaikan dengan keadaan suami. Keterangannya yaitu hadits istri Abu Sufyan yang telah disebutkan tadi dan firman Allah SWT:

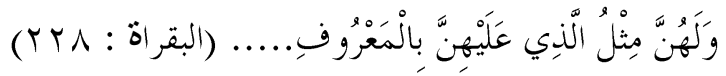

Dan para wanita mempunyai hak (nafkah) yang seimbang dengan kewajibannya menurut cara yang makruf (baik). (Q.S. AlBaqarah, 2: 228)

\section{c. Sebab Milik}

Seseorang yang memiliki binatang wajib memberi makan binatang itu, dan dia wajib menjaganya jangan sampai diberi beban lebih dari semestinya. (Rasyid, 2009 : 423). Rasulullah SAW bersabda:

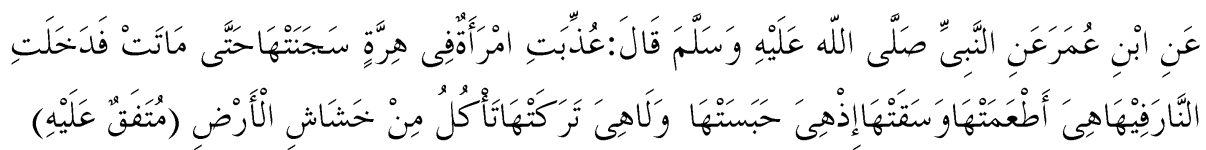

Dari Ibnu 'Umar ra., dari Nabi SAW, beliau bersabda: "seorang perempuan disiksa sebab seekor kucing yang dikurungnya hingga mati. Lalu ia masuk neraka sebab kucing itu. Ia tidak memberinya makan dan minum ketika ketika mengurungnya dan tidak pula ia melepaskan agar memakan binatang-binatang serang di tanah". (Sepakat Ahli Hadits) (Terjemah Bulugh al-Maram, 2014, cet. 1:323)

1) Hukum Nafkah

Hukum membayar nafkah untuk istri baik dalam bentuk perbelanjaan, pakaian, dan makanan adalah wajib. Kewajiban itu bukan disebabkan oleh karena istri membutuhkannya bagi kehidupan rumah tangga, tetapi kewajiban yang timbul dengan sendirinya tanpa melihat kepada keadaan istri. Bahkan di antara ulama Syi'ah menetapkan bahwa meskipun istri orang kaya dan tidak memerlukan bantuan biasa dari suami, namun suami tetap wajib membayar nafkah. (Mughniyah: 207).

Di antara ayat al-Qur'an yang menyatakan kewajiban perbelanjaan terdapat dalam surat Al-Baqarah ayat 233:

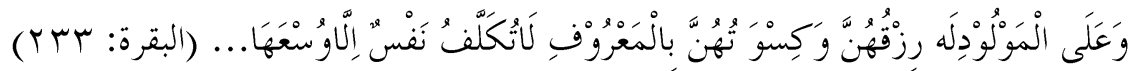

Dan kewajiban ayah menanggung nafkah dan pakaian mereka dengan cara yang patut. Seseorang tidak dibebani lebih dari kesanggupannya. (Q.S. Al-Baqarah, $2: 233$ )

Dan hadits Nabi Muhammad SAW: 


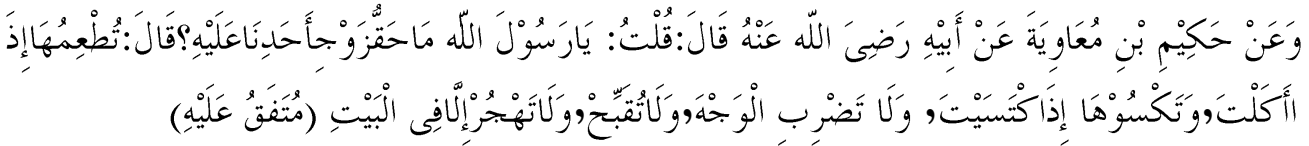

Dari Hakim Ibnu Mu'awiyah dari ayahnya ra., berkata: saya berkata: Ya Rasulallah, apa salah satu hak suami? Nabi SAW bersabda: "Hendaknya kamu memberinya makan jika kamu makan, dan memberinya pakaian jika kamu menggunakan pakaian, dan jangan memukul wajah, jangan menjelek-jelekkan, serta jangan berseteru kecuali di dalam rumah" (Sepakat Ahli Hadits) (Bulugh al-Maram, TT: 213)

2) Syarat-syarat Kepemilikan Hak Terhadap Nafkah

Untuk memiliki hak atas nafkah, beberapa syarat berikut harus terpenuhi, di antaranya:

a) Akad nikah dilaksanakan secara sah

b) Istri menyerahkan dirinya kepada suaminya

c) Istri menyediakan diri bagi suami untuk menikmati kesenangan dengan dirinya

d) Istri tidak menolak untuk pindah tempat sesuai dengan keinginan suami

e) Keduanya termasuk orang yang layak untuk dapat menikmati kesenangan dalam hubungan suami istri. (Sayyid Sabiq, Fiqih sunnah, 2008: 430)

Jika tidak terpenuhi satu syarat dari syarat-syarat tersebut, maka nafkah menjadi tidak wajib. Jika akad nikah tidak sah bahkan rusak, maka pasangan suami istri harus dipisah untuk menghindari dampak buruk. Demikian pula jika istri tidak menyerahkan dirinya kepada suaminya, atau tidak memberi kesempatan kepada suami untuk menikmati kesenangan hubungan dengannya, atau dia menolak untuk pindah ke tempat yang dituju oleh suaminya, dalam kondisi-kondisi ini, nafkah menjadi tidak wajib. (Sayyid Sabiq, Fiqih Sunnah Jilid 3, 2008: 430)

Nafkah tidak wajib ditunaikan jika istri pindah dari rumah yang ditempatinya dengan suami ke rumah lain tanpa izin suami dan tanpa alasan yang dibenarkan syariat, atau istri melakukan bepergian tanpa izin suami, atau melakukan ihram untuk menunaikan ibadah haji tanpa izin suami. Jika dia bepergian dengan izin suami, atau suami keluar bersamanya, maka nafkah tidak gugur (istri berhak menerima nafkah dari suami), karena dia tidak keluar dari ketaatan dan kewenangan suami. (Sayyid Sabiq, Fiqih Sunnah Jilid 3, 2008: 431)

Demikian pula nafkah tidak wajib ditunaikan jika istri ditahan dalam kasus kejahatan atau terkait hutang, atau dia ditahan lantaran kedzaliman, kecuali jika suami sendiri yang menahannya terkait hutangnya kepada 
suami, karena suamilah yang menyebabkan haknya sendiri terluputkan. Selain itu istri yang keluar untuk menekuni profesinya, jika suaminya melarangnya namun dia enggan, maka dia tidak berhak atas nafkah dari suaminya. (Sayyid Sabiq, Fiqih Sunnah Jilid 3, 2008: 432)

3) Jenis dan Ukuran Nafkah

Pada dasarnya berapa besar nafkah yang wajib diberikan oleh suami kepada istri adalah dapat mencukupi keperluan secara wajar, meliputi keperluan makan, pakaian, perumahan, dan sebagainya. Prinsip "mencukupi keperluan" dapat diperoleh dari hadits Nabi tentang dibenarkannya seorang istri mengambil uang suaminya tanpa izin apabila nafkah yang diberikan tidak mencukupi. (Ahmad Azhar Basyir, 1999: 57)

Kata "makruf", yang dipergunakan Al-qur'an dan hadits untuk member ketentuan nafkah, berarti nafkah itu diberikan secara wajar (sedang, tengah-tengah, tidak kurang dari kebutuhan tetapi tidak pula berlebihan), sesuai tingkat hidup dan keadaan istri dan kemampuan suami. Makruf bagi suami yang berpangkat tinggi lain dengan yang makruf bagi suami berpangkat rendah dan sebagainya. (Ahmad Azhar Basyir, 1999: 58)

Kata makruf juga dapat berarti bahwa hal-hal yang memang dirasakan menjadi kebutuhan hidup, seperti alat-alat rumah tangga, alatalat kerapian tata busana yang tidak melampaui batas, bahkan juga perhiasan sekadarnya apabila memang suami mampu, dapat termasuk halhal yang wajib diperhatikan suami. (Ahmad Azhar Basyir, 1999: 58)

Madzhab Hanafi berpendapat bahwasannya tidak ada ketentuan syariat terkait besaran nafkah, dan bahwasannya suami berkewajiban memenuhi kebutuhan istri secukupnya yang terdiri dari makanan, laukpauk, daging sayur mayur, buah, minyak, mentega, dan semua yang dikonsumsi untuk menopang hidup sesuai dengan ketentuan yang berlaku secara umum, dan semua itu berbeda-beda sesuai dengan perbedaan tempat, zaman, dan keadaan. Suami juga berkewajiban memenuhi sandang bagi istri pada musim panas maupun pada musim dingin. Mereka berpendapat bahwa besaran nafkah yang ditanggung suami disesuaikan dengan kondisi suami dari segi kelapangan atau kesulitan, terlepas bagaimanapun keadaan istri. (Sayyid Sabiq, 2008: 436)

Sedangkan menurut Madzhab Syafi'i, kadar nafkah tidak mengaitkan penetapan besaran nafkah dengan batas kecukupan. Mereka mengatakan, besaran nafkah ditetapkan berdasarkan ketentuan syari'at. Meskipun demikian, mereka sepakat dengan ketentuan madzhab Hanafi dalam mempertimbangkan keadaan suami dari segi kelapangan ataupun kesulitan, dan bahwasannya suami yang mengalami kondisi lapang, yaitu yang mampu memberikan nafkah dengan harta dan penghasilannya, harus menafkahi sebanyak dua mud setiap hari (satu mud kurang lebih setara dengan 543 gram). Sedangkan orang yang mengalami kesulitan, yaitu yang 
tidak mampu memberikan nafkah dengan harta tidak pula penghasilan, harus menafkahi sebanyak satu mud setiap hari. Adapun orang yang berbeda dalam kondisi pertengahan maka dia harus manfkahi sebanyak satu setengah mud. (Sayyid Sabiq, Fiqih Sunnag Jilid 3, 2008: 437)

Jika istri tinggal bersama suaminya dan suami memberinya nafkah dan menanggung segala kebutuhannya berupa makanan, pakaian dan lainnya, maka istri tidak berhak untuk meminta nafkah melebihi dari yang sudah diterimanya karena suami sudah memenuhi kewajiban yang ditunaikannya. Jika suami kikir dan tidak mau mencukupi kebutuhannya, atau membiarkan istrinya tanpa nafkah dengan alasan yang tidak benar, maka istri boleh menuntut nafkah yang seharusnya ia terima berupa makanan, pakaian dan tempat tinggal. Hakim pun berhak memberi keputusan untuk mewajibkan suami memberi nafkah kepada istri dan istri juga memiliki hak untuk mengambil harta suaminya secukupnya dengan cara wajar, meskipun tanpa sepengetahuan suami, karena suami enggan menunaikan kewajibannya sementara istri berhak untuk mendapatkannya dan orang yang boleh mengambil haknya dengan tangan sendiri kapanpun dia mampu melakukannya. (Sayyid Sabiq, Fiqih Sunnah Jilid 3, 2008: 434)

Dalam hal ini, besaran nafkah disesuaikan dengan kebutuhan istri dengan tetap mengacu pada asas kepatutan. Maksudnya, sesuai dengan kepatutan yang umum yang diketahui diantara masing-masing pihak dengan pertimbangan bahwa itulah yang terjadi secara umum dalam keluarganya. Hal ini berbeda-beda sesuai dengan perbedaan zaman, tempat, keadaan, dan masing-masing orang yang bersangkutan. (Sayyid Sabiq, Fiqih Sunnah Jilid 3, 2008: 434)

Penulis ar-Raudhah an-Nadiyah juga mengatakan, bahwa kewajiban orang yang menanggung nafkah terhadap orang yang ditanggung nafkahnya adalah mencukupi dengan sepatutunya. Namun demikian, ini tidak berarti penentuan hal tersebut diserahkan kepada pihak yang ditanggung nafkahnya dan dia mengambilnya sendiri hingga pada kondisi tertentu pemberi nafkah menolak apa yang dikehendakinya karena khawatir terhadap sikap berlebihan. Akan tetapi, maksudnya adalah menyerahkan kebutuhan secukupnya tanpa ada unsur berlebihan padanya setelah ada penjelasan mengenai besaran kebutuhan yang mencukupi dari kalangan yang berkompeten dalam hal ini, atau menurut orang-orang yang berkecimpung di dalamnya. (Sayyid Sabiq, Fiqih Sunnah Jilid 3, 2008: 435)

Di antara nafkah yang ditanggung suami bagi istrinya adalah kebutuhannya berupa sisir, sabun, minyak wangi dan segala yang dibutuhkan untuk pembersih badan. Pengikut madzhab Syafi'i mengatakan, adapun minyak wangi, jika diperlukan untuk menghilangkan bau yang tidak sedap, maka suami harus memenuhinya, karena kebutuhan ini dimaksudkan untuk kebersihan. Jika dimaksudkan untuk bersenang-senang 
dan kenyamanan saja, maka memberi minyak wangi bukan bagian dari keharusan yang hars ditunaikan suami, karena kepentingan tersebutt termasuk dalam hak suami, maka dia sebagai pemilik hak yang tidak dapat dipaksa. (Sayyid Sabiq, Fiqih Sunnah Jilid 3, 2008 : 436)

\section{METODE}

Sesuai dengan karakteristik masalah, tujuan dari kerangka pemikiran penelitian, metode yang digunakan dalam penelitian ini adalah penelitian studi kasus. Penelitian studi kasus bertujuan untuk mendeskripsikan suatu satuan analisis secara utuh, sebagai suatu kesatuan yang terintegrasi. Satuan analisis itu dapat berupa seorang tokoh, suatu keluarga, suatu peristiwa, suatu komunitas, dan lain sebagainya. (Mardalis, $1993: 26)$

\section{HASIL PENELITIAN DAN PEMBAHASAN}

Pendapat ulama Desa Sindangjaya Terhadap Pemberian Nafkah Istri kepada Suami

Berdasarkan hasil penelitian yang dilakukan kepada ulama Desa Sindangjaya Kecamatan Mangunjaya, tidak ditemukan perbedaan pendapat secara menonjol dalam menanggapi istri yang menafkahi suami atau keluarga. Kelimanya membolehkan istri bekerja jika ia melakukannya dengan kesadaran diri sendiri. Ulama-ulama tersebut antara lain:

1) Ustad Saeful Rohman

Menurut Ustad Saeful Rohman pada hakikatnya yang wajib menafkahi istri dan anak adalah suami. Suami bertanggungjawab memenuhi kebutuhan istri dan anak-anaknya untuk kelangsungan hidup yang lebih baik. Status pencari nafkah hanya dibebankan kepada suami saja. Namun dalam hal ini, jika istri mampu bekerja dengan niat membantu suami hukumnya yajuzu (boleh). Artinya seorang istri diperbolehkan bekerja hanya untuk membantu suami dan menambah penghasilan ekonomi keluarga saja.

Namun dewasa ini dalam perkembangan era globalisasi menunjukkan bahwa emansipasi atau kesetaraan gender mulai marak ditunjukkan oleh kaum wanita. Banyak wanita-wanita karir yang bekerja untuk memenuhi kebutuhan sehari-hari bahkan tidak sedikit dari mereka yang menganggap bahwa wanita bekerja adalah sebuah gaya hidup. Apalagi wanita yang memiliki latar belakang pendidikan yang cukup mumpuni akan sangat disayangkan jika keilmuannya tidak disalurkan dengan baik. Hal ini menunjukkan bahwa seorang wanita tidak lagi hanya berpangku tangan kepada laki-laki (suami). Ia mampu memenuhi kebutuhannya sendiri tanpa harus meminta kepada suami. 
Wanita berkarir memiliki prinsip hidup mandiri. Segala sesuatu yang menjadi kebutuhannya tidak ia gantungkan kepada suami. Bahkan ketika pangkat istri lebih tinggi dibandingkan suami, ia akan mampu menafkahi kebutuhan keluarga dengan penghasilannya sendiri.

Menurut Ustad Saeful Rohman ada tiga syarat seorang wanita muslimah bekerja yang wajib dipenuhi:

a) Pekerjaan tersebut tidak melanggar syari'at.

Di zaman modern seperti saat ini, banyak pekerjaan-pekerjaan yang seharusnya ditinggalkan karena menyimpang dari syari'at Islam. Misalnya seperti bekerja di bar-bar (diskotik) yang menghidangkan minuman keras. Banyak pelayan-pelayan wanita yang bekerja ditempat tersebut menghidangkan minuman keras untuk para pelanggan. Pekerjaan tersebut sangatlah tidak dianjurkan untuk wanita. Selain karena beresiko akan gangguan dari orang-orang pemabuk, juga karena haram hukumnya berdekatan dengan minuman yang memabukkan.

Selain itu, seorang wanita diharamkan bekerja melayani lelaki bujang atau pekerjaan yang mengharuskan ia berkhalwat dengan laki-laki. Dewasa ini wanita-wanita penghibur dan pemuas nafsu seperti di kota-kota besar semakin banyak bermunculan. Dari mulai usia belia sampai wanita yang sudah berkeluarga sekalipun. Banyak dari mereka yang mengatakan bahwa melakukan pekerjaan tersebut adalah sebuah keterpaksaan yang harus mereka lakukan karena tidak adanya pekerjaan lain. Padahal mereka mengetahui akibatnya akan berdampak pada dirinya sendiri. Selain banyaknya gunjingan dan hinaan dari masyarakat, mereka juga akan mendapatkan siksaan dari Allah SWT.

b) Menaati adab-adab ketika keluar rumah

Seorang wanita muslimah jika pekerjaannya mengharuskan ia bepergian, haruslah mengetahui aturan dan adab ketika berada di luar rumah. Sebagaimana dijelaskan dalam surat An-Nur ayat 31:

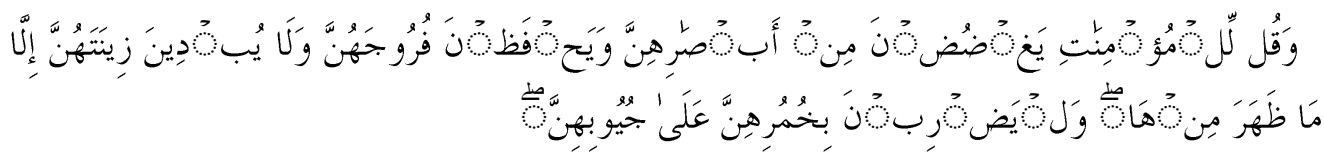

Dan katakanlah kepada para perempuan yang beriman, agar mereka menjaga pandangannya, dan memelihara kemaluannya, dan janganlah menampakkan perhiasannya (auratnya), kecuali yang (biasa) terlihat. Dan hendaklah mereka menutupkan kain kerudung ke dadanya. (Q.S. An-Nisa, 24: 31) 
Ayat di atas menjelaskan bahwa seorang wanita muslimah ketika bepergian harus selalu menjaga pandanganya dari hal-hal yang seharusnya tidak ia lihat. Misalnya seperti menjaga penglihatannya untuk tidak melihat aurat orang lain atau melihat kemaksiatan yang lainnya. Untuk itu, seorang wanita harus selalu berhati-hati dalam melangkah.

Di samping itu yang lebih utama adalah seorang wanita harus mampu menjaga dan memelihara auratnya. Dalam Kamus Besar Bahasa Indonesia aurat adalah bagian badan yang tidak boleh kelihatan (KBBI, Departemen Pendidikan Nasional: 77). Istilah lain menyebutkan bahwa aurat merupakan sebuah aib yang wajib ditutupi.

Dalam surat An-Nisa ayat 31 di atas menjelaskan bahwa seorang wanita harus menjaga kemaluannya dan menutupi perhiasan (auratnya). Ini menunjukkan bahwa seorang wanita haruslah menjaga kesuciannya dengan cara menutupi anggota tubuh yang tidak seharusnya terlihat. Menurut Madzhab Syafi'i dan Hanafi aurat wanita adalah di seluruh anggota tubuh sampai rambutnya yang terurai kecuali wajah dan kedua telapak tangan. (Barik, 2008: 148)

Dari penjelasan di atas menunjukkan bahwa haram hukumnya jika seorang wanita muslimah dengan sengaja menampakkan auratnya. Karena disadari atau tidak, ia telah memancing syahwat kaum laki-laki. Ia membiarkan laki-laki lain melihat anggota tubuhnya yang hanya boleh dilihat oleh mahramnya. Maka dari itu wanita muslimah wajib menutupi auratnya. Ketika berada di luar rumah atau hendak bepergian, seorang wanita harus memperhatikan pakaian yang akan dikenakannya untuk bisa menutupi seluruh bagian auratnya, seperti memakai jilbab hingga menutupi dadanya atau pakaian yang layak dipakai untuk seorang muslimah.

Dalam hal ini, aurat yang dimaksud bukan hanya aurat dalam arti anggota tubuh saja, melainkan kehormatan suami bahkan keluarganya. Ketika seorang istri berada di luar rumah maka ia harus bisa menjaga harga diri dan nama baik suami. Permasalahan dan keadaan rumah tangga harus tetap terjaga dengan baik. Karena hal tersebut bukanlah sebagai konsumsi publik, melainkan sebuah rahasia yang hanya diri sendiri yang boleh mengetahuinya.

c) Tidak boleh mengabaikan tugas utamanya untuk mengurus keluarga

Wanita bekerja memang diperbolehkan, akan tetapi dengan catatan hanya berniat untuk membantu suaminya bekerja. Karena pada dasarnya tidak ada yang mewajibkan seorang istri mencari nafkah. Namun tidak menjadi keharusan juga seorang istri membantu suaminya bekerja. Suami akan meridhoi dan mengizinkan istrinya bekerja jika istri tersebut tidak melanggar kodratnya sebagai wanita, sebagai istri, sekaligus sebagai ibu yang mengasuh anak-anaknya. 
Akan tetapi, istri bekerja akan menjadi haram apabila ia tidak melaksanakan kewajibannya sebagai istri. Salah satu kewajiban istri adalah melayani suami. Artinya melayani segala kebutuhan suami, baik kebutuhan rohaniah maupun bathiniah. Ketika suami meminta haknya untuk mendapatkan kesenangan dari istrinya, namun istri menolak dengan alasan lelah karena habis bekerja, maka sudah dipastikan bahwa istri tersebut berdosa dan pekerjaannya menjadi haram karena dijadikan alasan untuk menolak memenuhi kesenangan suaminya. Hal ini akan menimbulkan keretakan dalam rumah tangga. Hubungan suami istri tidak akan lagi harmonis, bahkan bisa jadi suami akan meninggalkan istrinya dan mencari wanita lain yang lebih mampu melayaninya dengan baik.

Meskipun di luar sana dia (istri) memiliki jabatan yang tinggi, akan tetapi ketika sudah masuk ke dalam rumah, seorang istri tetaplah menjadi ibu rumah tangga yang bertugas mengurus suami, anak, dan mengerjakan pekerjaan rumah lainnya.

Kebolehan istri bekerja bukan berarti tugas mencari nafkan dibebankan kepada istri, lantas suami hanya berdiam diri di rumah. Suami akan berdosa jika ia masih mampu bekerja dan masih memiliki kesehatan fisik yang baik tetapi tidak ada keinginan untuk bekerja. Hal ini menunjukkan tidak adanya tanggungjawab suami sebagai kepala rumah tangga. Kewajiban yang seharusnya dia lakukan malah dibebankan kepada istrinya, dan dia sendiri hanya berdiam diri di rumah tanpa melakukan apapun. Maka suami tersebut telah melakukan dosa karena menelantarkan dan memberikan penderitaan kepada istri.

Dalam kaitan ini, apabila suami yang sudah tidak mampu lagi mencari nafkah, misalnya jika suami dalam keadaan sakit dan karena itu dia tidak lagi memiliki kemampuan untuk memberikan nafkah kepada istri, maka istrilah yang bertugas mencari nafkah. Namun bukan berarti tugas mencari nafkah beralih kepada istri. Hanya saja untuk sementara waktu sampai suami bisa sehat kembali.

2) Ustad Dani

Pendapat yang sama dikemukakan oleh Ustad Dani tentang istri yang menafkahi suami. Menurut Ustad Dani, sebagai seorang pemimpin dalam rumah tangga, suami berkewajiban untuk mencukupi kebutuhan istri. Begitu pula jika ia telah dikaruniai seorang anak, maka tugasnya semakin bertambah. Bukan hanya membiayai hidup istrinya saja akan tetapi harus mencukupi kebutuhan anaknya juga.

Hidup berumah tangga bukan hanya menerima kelebihan pasangannya saja, tetapi juga harus menerima semua kekurangan yang ada. Selain itu dalam hubungan suami istri harus memiliki rasa kepedulian, saling menjaga dan menghargai satu sama lain. Terutama bagi seorang istri. 
Ketika suami memberikan rezeki yang lebih kepada istri, maka seorang istri harus bisa memanfaatkannya sebaik mungkin sesuai dengan kebutuhan. Namun sebaliknya jika suami memberikan rezeki yang kurang, maka istri yang shalehah harus tetap menerimanya dengan ikhlas tanpa mengeluh sedikitpun.

Seorang istri harus bisa menerima segala bentuk pemberian suami. Menghargai usaha yang telah dilakukan suami sama halnya dengan mensyukuri nikmat dan karunia yang telah Allah berikan. Meskipun rezeki yang didapatkan terbilang sedikit, namun dengan usaha yang keras, rajin bekerja, dan selalu berdoa maka Allah SWT. akan selalu melapangkan pintu rezeki kepadanya. Allah akan memberikan apa yang umat-Nya butuhkan, bukan memberikan apa yang umat-Nya inginkan. Dengan kata lain, berapapun usaha yang didapatkan suami, berapapun rezeki yang telah diberikan oleh Allah, maka akan cukup untuk memenuhi segala kebutuhan rumah tangga jika istri pandai memanfaatkannya.

Peran seorang istri juga sangat berpengaruh terhadap keberhasilan suami. Ada sebuah pepatah mengatakan, "dibalik kesuksesan suami, ada istri yang hebat". Artinya, seorang istri yang baik akan selalu mendukung suami dalam menjalankan kewajibannya. Istri yang hebat akan senantiasa memberikan memotivasi dan semangat kepada suaminya untuk selalu giat berusaha dalam mencari nafkah. Selain itu, istri yang shalehah akan selalu mendoakan kesuksesan suaminya dalam bekerja.

Namun ketika suami mengalami suatu kondisi di mana ia tidak lagi mampu bekerja untuk mencari nafkah (dalam arti sakit), maka boleh saja seorang istri menafkahi suaminya. Bisa saja seorang istri menggantikan peran suaminya sebagai pencari nafkah untuk sementara waktu, jika ia ridho dan melakukannya dengan ikhlas.

Istri yang baik akan memiliki kelapangan hati dan menerima setiap kondisi dan keadaan apapun bahkan situasi yang berat sekalipun. Istri yang mampu menerima kondisi suaminya yang sakit akan memiliki rasa kepedulian yang tinggi serta memiliki inisiatif untuk bisa membantu suami dalam menggantikan perannya sebagai pencari nafkah.

Bisa diambil sebagai contoh kisah dari Nabi Ayub as. Ayyub adalah putra 'Ish bin Ishaq bin Ibrahim. Nabi Ayyub adalah seorang Nabi yang sangat kaya raya. Istananya megah, rezekinya berlimpah ruah, ternaknya tak terbilang jumlahnya, istri dan anaknya sehat wal'afiat. Lebih penting dalam kemakmurannya itu Ayyub tetap menjadi seorang hamba Allah yang saleh dan kuat ibadahnya. Banyaknya harta tidak membuat beliau sombong dan angkuh. Tetapi sebaliknya, beliau adalah seorang penderma dan amat suka menolong orang-orang yang lemah dan miskin.

Kekayaannya yang melimpah ruah dan rumah tangganya yang sakinah, tidak menjadikan Ayyub lalai atau mabuk. Dia bahkan semakin 
tekun dengan bersujud dan berbakti kepada Allah SWT. Demikian juga istrinya yang bernama Siti Rahmah.

Suatu saat ketika para malaikat membicarakan manusia dan sejauh mana mereka beribadah kepada Allah, salah seorang di antara mereka berkata: "Tidak ada di muka bumi ini seorang yang lebih baik daripada Nabi Ayub. Beliau adalah orang mukmin yang paling sukses, orang mukmin yang paling agung keimanannya, yang paling banyak beribadah kepada Allah SWT. dan bersyukur atas nikmat-nikmat-Nya dan selalu berdakwah di jalan-Nya." Para Malaikat sampai kagum melihat ketaatan Nabi Ayyub as.

Iblis mendengarkan pembicaraan para malaikat merasa iri dan ingin menjerumuskan Nabi Ayyub agar tidak menjadi orang sabar. Lalu Iblis mencoba mendatangi Nabi Ayyub untuk menggodanya. Tetapi karena keimanannya kepada Allah, Iblis kesulitan mendapatkan jalan untuk mengganggunya. Iblis kemudian menghadap Allah untuk meminta izin menggoda Nabi Ayyub: "Wahai Allah, sesungguhnya Ayyub senantiasa patuh dan taat kepadaMu hanya karena ia tidak ingin kehilangan semua nikmat yang telah Engkau karuniakan kepadanya. Semua ibadajnya tidak ikhlas dan bukan karena cinta dan taat kepadaMu. Andaikan ia tertimpa musibah dan kehilangan istri dan anak-anaknya, kehilangan harta bendanya, belum tentu ia akan tetap taat dan patuh kepada-Mu".

Allah berfirman: "Sesungguhnya Ayyub adalah hamba-Ku yang sangat taat dan patuh kepada-Ku. Ia adalah seorang muslim sejati. Apa yang ia lakukan untuk mendekatlan diri kepada-Ku adalah semata-mata dorongan keimanannya kepada-Ku. Iman dan taqwanya tidak akan tergoyahkan oleh perubahan keadaan duniawi, cintanya kepada-Ku yang sewaktu-waktu dapat Kucabut. Kamu tidak rela melihat hamba-hamba-Ku berada di atas jalan yang lurus sesuai petunjuk-Ku. Untuk menguji keteguhan hati dan keyakinannya kepada takdir-Ku, Kuizinkan semua pembantu-pembatumu untuk menggoda Ayyub melalui harta dan keluarganya. Hancurkan harta bendanya. Cerai-berailah keluarganya yang damai dan sejahtera itu. Aku ingin melihat sampai di mana kemampuanmu menggoda hamba-Ku yang ikhlas seperti Ayyub itu".

Lalu Iblis pun datang kepada nabi Ayyub lalu menghancurkan semua harta-hartanya. Iblispun kemudian turun menghancurkan segala milik Ayyub. Semua kebun dan tanahnya yang dulu subur kini menjadi kering dan terbakar. Binatang ternaknya terserang wabah menular yang kemudian mati semua. Akan tetapi Ayyub tidak bersedih sama sekali, bahkan semakin tekun dia bersujud. Nabi Ayyub tetap bersyukur dan berbaik sangka kepada Allah. Segalanya ia serahkan kepada Allah karena ia yakin bahwa hartanya adalah titipan Allah semata dan dapat dicabut kapan saja. 
Setelah usahanya gagal iblis datang kepada Allah lalu meminta ijin untuk membunuh anak-anak Nabi Ayub. Dengan izin Allah, iblis dibolehkan berbuat apapun kepada anak Ayub. Lalu iblispun menggoncangkan rumah Nabi Ayyub sehingga anak-anak Nabi Ayyub meninggal semua. Maka Iblis itu segera menyebarkan wabah penyakit dan bencana. Semua anak Ayyub meninggal, istana tempat tinggal mereka hancur hingga menjadi puing-puing karena gempa.

Melihat keadaan itu Nabi Ayyub pun berdoa kepada Allah dan menyeru: "Allah memberi dan Allah mengambil. Maka bagi-Nya pujian saat Dia memberi dan mengambil, saat Dia murka dan ridha, saat Dia mendatangkan manfaat dan mudharat. Kemudian Ayyub pun sujud dan iblis lagi-lagi tampak tercengang dan merasa malu karena kesabaran Nabi Ayyub. Melihat kejadian-kejadian yang menimpa dirinya, Ayyub hanya memandangnya dengan meneteskan air mata. Dari mulutnya hanya keluar ucapan tawakal dan pasrah diri.

Tidak cukup sampai disitu Iblis meminta izin lagi kepada Allah untuk mengganggu badan Nabi Ayyub. Iblis menaburkan baksil dan bakteri di sekujur tubuh Nabi Ayyub sehingga beliau menderita penyakit kulit di mana tubuhnya membusuk dan mengeluarkan nanah. Keluarga dan sahabat-sahabatnya yang dulu sangat baik kepadanya kini menjauhinya. Satu-satunya orang yang masih setia merawat beliau adalah istrinya Rahmah. Namun lagi-lagi Nabi Ayyub tetap bersabar dan bersyukur kepada Allah SWT. Beliau memuji-Nya pada hari-hari kesehatannya dan ia tetap memuji Allah SWT. saat mendapatkan ujian sakit. Dalam dua keadaan itu, Nabi Ayyub tetap bersabar dan bersyukur kepada Allah SWT. Semua orang tak ada yang mau menjenguk atau mendekatinya karena bau tubuh Ayyub bisa membuat orang muntah-muntah, dan juga karena takut tertular penyakit yang menjijikkan itu. Hanya Rahmah, istrinya, yang dengan sabar mendampingi Ayyub, merawatnya dengan baik. Kudis bernanah yang penuh dengan ulat dicucinya tiap hari. Padahal semua orang yang lewat harus mendekap hidungnya karena tak kuat mencium bau busuknya.

Akhirnya sampailah penderitaan Ayyub dan istrinya pada puncaknya. Orang kampung berduyun-duyun mendatangi rumah Ayyub. Dengan paksa dan disertai ancaman mereka mengusir Ayyub dan istrinya agar segera keluar dari kampung mereka. Dengan susah payah Rahmah menggendong suaminya dan tinggal di sebuah gubuk terpencil di tepi hutan.

Tiap hari Rahmah keluar menjual sisa-sisa barang miliknya untuk dibelikan makanan. Hingga akhirnya sisa barang yang dimilikinya habis. Dalam keadaan kelaparan, Rahmah kemudian mencari pekerjaan, dia diterima disebuah pabrik roti. Tetapi, ketika diketahui bahwa dia adalah istri Ayyub, pemilik pabrik roti itu buru-buru memecatnya, karena takut jika nanti rotinya tidak laku terjual. Karena merasa putus asa Rahmah 
kemudian memotong rambutnya yang panjang dan ikal untuk dijual sekedar digunakan membeli roti. (Hasan, t,t.: 87)

Dari kisah Nabi Ayyub tersebut, terlihat bahwa betapa besar pengorbanan yang dilakukan oleh seorang istri kepada suaminya. Dalam kondisi apapun, seorang istri yang shalehah akan selalu mendampingi, setia, dan taat kepada suaminya. Kesabaran dan pengorbanan yang dilakukan Rohmah dalam mencari pekerjaan, semata-mata hanya untuk membantu suaminya yang sedang mengalami musibah. Hal itu menunjukkan bahwa ketika suami dalam ketidakberdayaan, maka istri akan bertanggungjawab mengurus dan memenuhi kebutuhan suaminya. Ia tidak akan membiarkan suaminya lebih menderita lagi.

Sama halnya dengan Ustad Saeful Rohman, Ustad Dani pun memiliki pendapat bahwa sangat berdosa bagi suami yang masih bisa untuk berusaha mencari nafkah namun justru dengan sengaja melimpahkan tugasnya kepada istri, padahal ia masih mampu untuk bekerja. Peran dan tugas masing-masing seolah ditukar, istri mencari nafkah dan suami hanya berdiam diri di rumah mengurus rumah tangga.

Ketika suami hanya bisa berdiam diri di rumah tanpa ada usaha untuk bekerja, maka hal tersebut akan menimbulkan perselisihan dengan istrinya. Jika istri tidak menerima dengan perbuatan suaminya itu, secara otomatis akan memancing pertengkaran dalam rumah tangganya. Akibatnya akan berdampak buruk terhadap psikologi anak yang secara langsung menyaksikan perdebatan antara ibu dan ayahnya. Selain dari mendapatkan dosa, rumah tangganya pun tidak akan harmonis bahkan perceraian pun bisa saja terjadi.

3) Kyai Achmad Saepulloh

Sementara menurut Kyai Achmad Saepulloh, istri yang menafkahi suami menjadi sebuah hal yang lumrah dan banyak terjadi di masyarakat. Tidak dapat dipungkiri bahwa pada zaman modern seperti saat ini wanita mendapat akses penuh dalam pendidikan dan pekerjaan. Hasilnya istilah wanita karir sudah sangat akrab di kalangan masyarakat.

Saat menjemput takdir menikah, seorang istri dibatasi oleh hak lakilaki yang menjadi suaminya. Tuntutan bekerja tidak lagi wajib sebagai seorang wanita. Karena suami mengambil tanggungjawab itu selepas akad nikah. Akan tetapi jika kondisi suami yang dalam keadaan tidak berdaya dan menderita karena sakit, atau karena pendidikan suami yang lebih rendah dibandingkan istri, atau bahkan faktor kemalasan, sehingga suami memilih diam di rumah tanpa adanya keinginan untuk bekerja, maka sebagai wanita yang mapan istri mengambil alih tanggungjawab untuk menafkahi suami. 
Dalam permasalahan seperti ini, hukum wanita bekerja diperbolehkan. Ketika seorang istri ikhlas dan ridha melaksanakan tugas yang seharusnya dilakukan suaminya maka hal itu akan mendatangkan sebuah amal kebaikan bagi istri tersebut. Jika memang dia bersedia dan rela berkorban demi suaminya daripada harus mempertaruhkan kehancuran rumah tangganya, maka sah-sah saja seorang istri menafkahi suaminya yang pengangguran. Kecuali apabila dia (istri) tidak rela ditelantarkan suaminya tanpa diberikan nafkah, maka istri tersebut bisa mengadukan perceraian ke Pengadilan Agama.

Menurut Kyai Achmad Saepulloh, seorang suami harus berusaha sekuat kemampuannya untuk memberi nafkah kepada istrinya. Meskipun dalam kondisi sedang sakit, kewajiban ini tidak lantas gugur dengan sendirinya. Bahkan jika ia sengaja tidak bekerja maka perbuatan suami tersebut digolongkan ke dalam dosa besar.

Di sisi lain, baik seorang suami itu bekerja atau tidak, ia tetap pemimpin dari istrinya. Artinya meski memiliki penghasilan, seorang istri tidak boleh merendahkan atau menolak taat kepada suaminya, sepanjang perintah sang suami tidak dalam bentuk kemaksiatan. Seorang istri harus tetap menghormati dan menjalankan tugas utamanya sebagai ibu rumah tangga, yaitu mengurus dan mematuhi suaminya.

Pada dasarnya, harta yang dihasilkan dari pekerjaan istri sepenuhnya milik istri. Jika ia menggunakannya untuk menafkahi suami atau bahkan keluarga, maka hal itu termasuk ke dalam sedekah dan kemuliaan, bukan sebuah kewajiban yang harus dipenuhi istri. Karena pada prinsipnya tetap yang memiliki tanggungjawab untuk memenuhi kewajiban menafkahi adalah suami.

Menurut Kyai Achmad Saepulloh, nafkah merupakan hak istri yang menjadi kewajiban suami untuk bisa memenuhinya. Jika suami tidak mampu memberikannya, maka sikap istri (Kurdi, t,t.: 375):

a) Boleh menuntut fasakh

Dalam Kamus Besar Bahasa Indonesia fasakh adalah hukum pembatalan ikatan pernikahan oleh Pengadilan Agama berdasarkan dakwaan (tuntutan) istri atau suami yang dapat dibenarkan oleh Pengadilan Agama atau karena pernikahan yang telah terlanjur menyalahi hukum pernikahan. (Departemen Pendidikan Nasional, 2001: 314)

Kata fasakh berarti merusakkan atau membatalkan. Jadi, fasakh sebagai salah satu sebab putusnya perkawinan ialah merusakkan atau membatalkan hubungan perkawinan yang telah berlangsung. Fasakh dapat terjadi karena terdapat hal-hal yang membatalkan akad nikah dan dapat pula terjadi karena sesuatu hal yang baru dialami sesudah akad nikah dilakukan atau sudah berlangsungnya kehidupan berumah tangga. Fasakh 
ada yang memerlukan putusan pengadilan dan ada juga fasakh yang tidak memerlukan putusan pengadilan.

Jadi, jika suami tidak mampu lagi untuk menafkahi dan istri tidak meridhoinya, maka ia (istri) boleh mengajukan fasakh nikah.

b) Tidak boleh menuntut fasakh, tetapi istri wajib bersabar

Seorang istri harus tetap menerima suami dalam keadaan apapun. Terlebih ketika suami dalam keadaan tersulit sekalipun, istri harus tetap setia mendampingi suami. Apalagi suami yang tidak mampu menafkahi karena sakit, istri harus bisa mengurus dan menjaganya karena berbakti kepada suami. Selain itu, istri harus mampu memberikan semangat dan dorongan kepada suami untuk berusaha mencari pekerjaan apabila suaminya menganggur.

c) Tidak boleh menuntut fasakh, istri yang kaya wajib menafkahi suami yang miskin

Sebelum memutuskan untuk hidup berumah tangga, banyak di antaranya kehidupan suami dan istri memiliki derajat sosial yang berbeda. Menjadi hal biasa jika suami lebih kaya daripada istrinya. Namun terkadang, ada juga istri lebih kaya dibandingkan suaminya. Dalam hal ini, ketika suami tidak mampu memberikan nafkah, maka istri yang kaya wajib menafkahi suaminya yang miskin.

Istri diperbolehkan memilih antara tetap bersama suaminya dengan kesusahannya atau berpisah dari suaminya dengan fasakh aqad nikah, dan nafkah bagi istri tidak wajib atas suaminya selama dia kesusahan.

Kyai Achmad Saepulloh berpendapat bahwa seorang istri boleh berhutang atas tanggungan suaminya untuk memenuhi nafkah apabila dalam keadaan suami tidak mampu memberikan nafkah. Artinya istri boleh meminta pinjaman kepada orang lain dan suaminyalah yang akan melunasi pinjaman tersebut.

4) Ustad Ida Rusda

Pendapat yang sama pun diungkapkan oleh Ustad Ida Rusda. Beliau mengatakan bahwa pada dasarnya ada tiga sebab seseorang diwajibkan untuk menafkahi, antara lain:

a) Karena pernikahan

Ketika seorang laki-laki dan perempuan terikat dalam suatu hubungan pernikahan, maka akan berlaku satu kewajiban di mana suami bertanggungjawab menafkahi dan memenuhi kebutuhan istrinya. Kebutuhan di sini termasuk di dalamnya berupa pakaian, makanan, dan tempat tinggal. 


\section{b) Karena kerabat atau keluarga}

Dalam menjalankan kehidupan bermasyarakat, seseorang harus tetap menjaga dan menjalin silaturahmi dengan keluarga, kerabat, maupun anggota masyarakat lainnya. Menafkahi kerabat atau keluarga menjadi wajib apabila mereka dalam kesulitan. Firman Allah:

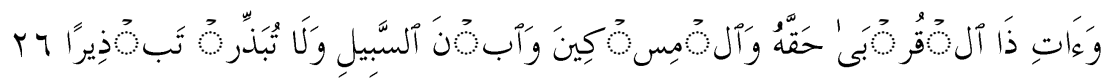

Dan berikanlah haknya kepada kerabat dekat, juga kepada orang miskin dan orang dalam perjalanan, dan janganlah kamu menghamburhamburkan (hartamu) secara boros. (Q.S. Al-Isra, 17: 25)

Dalam ayat ini Allah SWT. mewajibkan pemberian hak atas nafkah kepada para kerabat dekat, karena itu hendaklah seseorang tidak mengabaikan kerabat dekatnya dalam keadaan meminta atau membiarkan mereka mati kelaparan, kedinginan, dan binasa, atau tidak diberi tempat tinggal sehingga mereka tersengat matahari, kehujanan, dan diterpa angin. Maka apabila ia termasuk memiliki harta yang cukup, dimana atas kekayaan itu kerabat dekatnya berhak mendapatkan nafkah.

c) Karena milik (hewan)

Mereka yang memiliki hewan ternak atau hewan peliharaan, wajib memberikan makanan dan menjaga hewan tersebut jangan sampai menelantarkan dan membiarkannya kelaparan.

Dari ketiga sebab seseorang wajib menafkahi di atas menjelaskan bahwa suami memiliki tanggungjawab untuk menafkahi istri sebagai akibat dari adanya ikatan pernikahan. Nafkah merupakan kewajiban yang harus dipenuhi suami dan hak yang harus diterima istri. Memberikan makanan, pakaian, bahkan tempat tinggal yang layak untuk istri adalah tugas suami. Akan tetapi suami memberikan kebutuhan keluarga harus sesuai dengan kemampuan yang dimiliknya tanpa harus memaksakan diri untuk hidup berlebih-lebihan.

Seiring dengan berjalannya waktu, kebutuhan hidup semakin bertambah. Ada kalanya hal-hal tidak terduga terjadi dengan tiba-tiba. Tanpa persiapan yang dilakukan, anggaran rumah tangga menjadi bertambah pula. Jika hanya mengandalkan pendapatan suami, maka semua kebutuhan akan sangat sulit terpenuhi, sehingga peran istri mampu diandalkan untuk ikut serta membantu perekonomian keluarga. Jika pendapatan suami tidak memcukupi maka sah-sah saja istri ikut berusaha untuk bekerja dengan syarat istri ridha dan ikhlas melakukannya.

Jika melihat fenomena di masyarakat, selain untuk membantu suami meningkatkan tarap hidup yang lebih baik dan meningkatkan perekonomian keluarga, istri yang bekerja merupakan suatu upaya untuk 
mengganti peran suami sebagai pencari nafkah. Alasannya karena keadaan suami yang sudah tidak mampu menafkahi istri dikarenakan sakit atau berusia tua renta sehingga suami tidak berdaya lagi untuk bekerja. Dalam hal ini istri pun diperbolehkan menafkahi suami dengan catatan istri tersebut melakukannya dengan ikhlas.

Keikhlasan yang dimiliki oleh istri menciptakan suatu kesadaran bahwa kehidupan akan terus berjalan dan kebutuhan hidup akan selalu menjadi tuntutan yang harus selalu terpenuhi. Sehingga tidak mungkin istri membiarkan rumah tangganya berada dalam kesulitan. Maka dari itu, bekerja menggantikan suami mencari nafkah adalah suatu hal yang harus dilakukan. Namun bukan berarti tugas tersebut beralih ke pundak istri. meskipun suami dalam keadaan yang tidak mampu memberikan nafkah, akan tetapi status pencari nafkah dan kewajiban mencari nafkah tetap berada pada tanggungjawab suami.

Alasan lain menyebutkan bahwa istri bekerja adalah karena suami yang tidak mau berusaha. Seperti yang telah disebutkan sebelumnya bahwa perihal istri bekerja tidak menjadi masalah apabila ia bersedia dan ikhlas melakukannya. Akan tetapi, jika istrinya tidak menerima keadaan suami yang tidak bekerja, maka akan menjadi beban dosa untuk suami itu sendiri. Sebab tidak adanya ikhtiar dari suami untuk mencari pekerjaan. Karena tentu saja, jika melihat hukum yang ada, suamilah yang harus memberikan nafkah kepada istri.

5) Ustadzah Anih Ruhaeni

Pendapat Ustadzah Anih Ruhaeni sama dengan empat pendapat sebelumnya. Ia mengatakan bahwa nafkah yang harus ditunaikan suami tergantung dari latar belakang keluarga istrinya tersebut.

Menurut Ustadzah Anih Ruhaeni, apabila istri berasal dari keluarga kaya raya, maka setiap harinya suami harus memberikan nafkah sebesar 3 dinar (1 dinar sama dengan Rp. 120.000). Hal ini agar kehidupan istri sebelum dan sesudah menikah tetap sama, artinya tidak ada penurunan. Apabila istrinya berasal dari keluarga menengah, maka nafkah yang harus diberikan sebesar 2 dinar. Akan tetapi jika istri berasal dari keluarga yang miskin atau keluarga dengan status sosial yang rendah, maka nafkah yang diberikan sebesar 1 dinar setiap harinya. Namun pada kenyataannya, meskipun derajat istri lebih tinggi dibandingkan dengan suami, maka istri akan mengimbangi dengan keadaan suami. (Nawawi, t,t.: 3-6)

Terkait dengan istri yang menafkahi suami karena suaminya yang sudah tidak mampu bekerja dalam arti sakit, maka istrilah yang menanggung beban untuk menggantikan suami mencari nafkah. Namun tetap saja bukan berarti kewajiban suami gugur untuk menanggung beban 
sebagai pencari nafkah. Pendapat Ustadzah Anih ini sama dengan pendapat-pendapat ulama yang lainnya.

Pendapat yang sama pun diungkapkan oleh Ustadzah Anih Ruhaeni mengenai istri yang harus menghadapi suaminya yang menganggur tanpa adanya pekerjaan. Menurutnya, seorang istri tidak memiliki kewajiban untuk menafkahi suaminya yang malas bekerja. Akan tetapi penerapan yang terjadi di masyarakat kebanyakan istri tidak akan tinggal diam menghadapi suaminya yang hanya diam di rumah. Istri yang akan bertanggungjawab untuk memenuhi segala kebutuhan rumah tangga yang dibutuhkan. Namun tidak dipungkiri bahwa banyak juga yang memilih untuk mengambil jalan perceraian dengan alasan suami yang tidak menafkahi.

Perceraian adalah salah satu hal yang boleh dilakukan (halal), tapi sangat dibenci oleh Allah SWT. Oleh karena hal itu, pemerintah Republik Indonesia melalui Peraturan Pemerintah (PP) No. 9 Tahun 1975 tentang Pelaksanaan Undang-Undang No. 1 Tahun 1974 Tentang Perkawinan memberikan batasan-batasan alasan cerai yang diperbolehkan serta dapat diterima di Pengadilan.

Salah satu alasan perceraian yang diperbolehkan terkait permasalahan ini adalah menurut Pasal 19 ayat (5) PP No. 9 Tahun 1975 yang berbunyi "Salah satu pihak mendapat cacat badan atau penyakit dengan akibat tidak dapat menjalankan kewajibannya sebagai suami/isteri". (Subekti dan Tjitrosudibio, 1996: 567)

Dari salah satu alasan perceraian yang telah disebutkan di atas, apabila dikaitkan dengan permasalahan yang tengah dikaji menjelaskan bahwa jika suami memiliki penyakit atau cacat badan, sehingga ia tidak mampu lagi menafkahi dan karena itu istri tidak ridha, maka istri boleh mengajukan perceraian ke Pengadilan.

Di samping alasan perceraian tersebut di atas, melanggar shigat taklik talak juga bisa menjadi salah satu alasan mengajukan gugatan perceraian. Shigat taklik talak merupakan sebuah ikrar atau janji yang diucapkan suami pada saat akad pernikahan.

Shigat taklik talak sendiri dapat dilihat pada buku nikah yang mana isinya terdiri dari 4 poin sebagai berikut :

a) Meninggalkan istri saya 2 (dua) tahun berturut-turut;

b) Tidak memberi nafkah wajib kepadanya 3 (tiga) bulan lamanya;

c) Menyakiti badan/jasmani istri saya; atau

d) Membiarkan (tidak memperdulikan) istri saya 6 (enam) bulan lamanya;

Dan karena perbuatan saya tersebut istri saya tidak ridho dan mengajukan gugatan kepada Pengadilan Agama, maka apabila gugatannya 
diterima oleh oleh Pengadilan Agama tersebut, kemudian istri saya membayar Rp. 10.000,- (sepuluh ribu rupiah) sebagai iwadh (pengganti) kepada saya, maka jatuhlah talak saya satu kepadanya.

Jika ada satu atau lebih dari satu poin alasan cerai yang sesuai dengan kondisi, maka surat permohonan cerai atau surat gugatan cerai bisa langsung dibuat dengan menyertakan alasan tersebut. Begitu pula pada saat suami sudah tidak menafkahi istri selama waktu yang telah ditentukan di atas, maka istri boleh saja mengajukan gugatan perceraian ke Pengadilan Agama.

Dasar Hukum yang Digunakan Ulama Pedesaan tentang Pemberian Nafkah Istri kepada Suami

Mengenai dasar hukum tentang pemberian nafkah istri kepada suami, memang tidak ada nash yang secara tertulis membolehkan dan melarangnya, baik dalam al-Qur'an maupun dalam al-Hadits. Sebagaimana kaidah ushul:

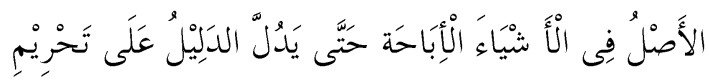

Asal dari setiap perkara itu adalah mubah (boleh) sehingga ada dalil yang menunjukkan keharamannya. (Mujib, 1996: 25)

Dari permasalahan yang saat ini menjadi berbincangan, di antara kelima tokoh masyarakat yang telah dimintai pendapatnya mengatakan bahwa hukum istri menafkahi suaminya adalah mubah (boleh), dengan syarat istri tersebut ikhlas melakukannya. Karena pada dasarnya istri tidak diwajibkan menafkahi suami meskipun suami dalam kondisi sulit sekalipun. Sebab sudah jelas disebutkan bahwa yang wajib menafkahi adalah suami.

1) Ustad Saeful Rohman

Menurut Ustad Saeful Rohman, dari berbagai sumber hukum dijelaskan bahwa suami-lah yang bertanggung jawab menafkahi istrinya. Karena dalam suatu hubungan pernikahan tentunya antara suami dan istri harus mengetahui hak dan kewajiban masing-masing. Sebagaimana yang termuat dalam Kompilasi Hukum Islam (KHI) pasal 80 tentang kewajiban suami yang berbunyi (Kompilasi Hukum Islam, 1991, hal. 41):

a) Suami adalah pembimbing terhadap istri dan rumah tangganya, akan tetapi mengenai hal-hal urusan rumah tangga yang penting-penting diputuskan oleh suami istri bersama

b) Suami wajib melincungi istrinya dan memberikan segala keperluan hidup berumah tangga sesuai dengan kemampuannya 
c) Suami wajib memberi pendidikan agama kepada istrinya dan memberi kesempatan belajar pengetahuan yang berguna dan bermanfaat bagi agama, nusa, dan bangsa

d) Sesuai dengan penghasilannya suami menanggung:

a. Nafkah, kiswah dan tempat kediaman bagi istri

b. Biaya rumah tangga, biaya perawatan dan biaya pengobatan bagi istri dan anak

c. Biaya pendidikan bagi anak.

a) Kewajiban suami terhadap istrinya seperti tersebut pada ayat (4) huruf a dan $b$ di atas mulai berlaku sesudah ada tamkin sempurna dari istrinya

b) Istri dapat membebaskan suaminya dari kewajiban terhadap dirinya sebagaimana tersebut pada ayat (4) huruf a dan b

c) Kewajiban suami sebagaimana dimaksud ayat (5) gugur apabila istri nusyuz.

Dari pasal 80 Kompilasi Hukum Islam (KHI) yang telah disebutkan di atas bahwa kewajiban suami adalah menafkahi istri beserta anaknya. Kewajiban tersebut mulai berlaku setelah terjadinya akad pernikahan. Suami wajib memberikan perlindungan kepada istrinya dan memberikan segala keperluan hidup rumah tangga sesuai dengan kemampuannya. Artinya, suami tidak diperkenankan untuk memberikan kesulitan dan penderitaan kepada istrinya, baik segi materil maupun moril.

Terkait dengan permasalahan yang dikaji, tentu saja istri tidak diwajibkan untuk menafkahi suami. Dalam Kompilasi Hukum Islam (KHI) pasal 83 ayat (1) tentang kewajiban istri menyebutkan bahwa "Kewajiban utama bagi seorang istri ialah berbakti lahir dan batin kepada suami di dalam batas-batas yang dibenarkan oleh hukum Islam". Dengan kata lain istri hanya memiliki kewajiban untuk mematuhi dan menaati suami selama masih dalam batas kewajaran.

Menurut Ustad Saeful Rohman, antara suami dan istri harus saling menjaga keutuhan rumah tangga. Permasalahan yang akan meruntuhkan kedamaian dalam keluarga harus dihindari. Seperti masalah yang berhubungan dengan nafkah suami. Hal ini menjadi persoalan yang sensitif dalam kehidupan berumah tangga. Maka dari itu, baik istri maupun suami harus mampu memelihara hubungan keluarga. Sebagaimana perintah Allah dalam surat An-Nisa ayat 1:

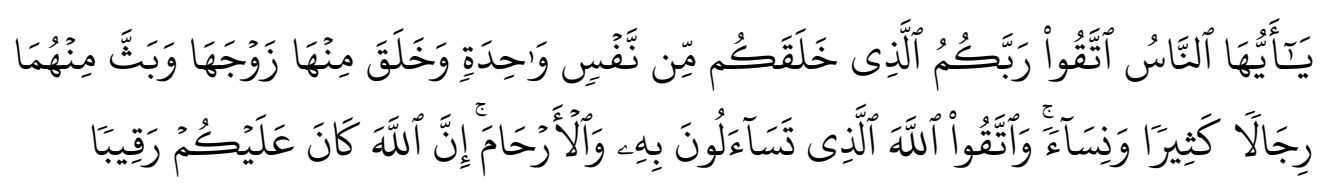


1. O mankind, fear your Lord, who created you from one soul and created from it its mate and dispersed from both of them many men and women. And fear Allah, through whom you ask one another, and the wombs. Indeed Allah is ever, over you, an Observer.

Wahai manusia! Bertaqwalah kepada Tuhanmu yang telah menciptakan kamu dari diri yang satu (Adam), dan (Allah) menciptakan pasangannya (Hawa) dari (diri)nya, dan dari keduanya Allah memperkembang biakkan laki-laki dan perempuan yang banyak. Bertaqwalah kepada Allah yang dengfan nama-Nya kamu saling meminta dan (peliharalah) hubungan kekeluargaan. Sesungguhnya Allah selalu menjaga dan mengawasimu. (Q.S. An-Nisa, 4: 1).

2) Ustad Dani, Ustadzah Anih Ruhaeni, dan Kyai Achmad Saepulloh

Menurut pendapat Ustad Dani, Ustadzah Anih Ruhaeni, dan Kyai Achmad Saepulloh, dasar hukum yang diambil untuk menanggapi istri yang menafkahi suami mengacu pada surat An-Nisa ayat 34, yang berbunyi:

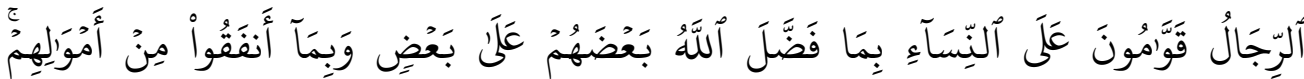

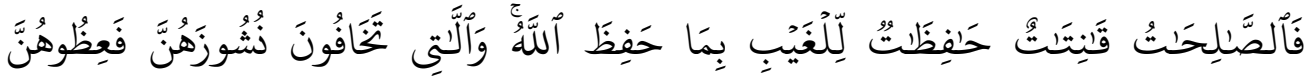

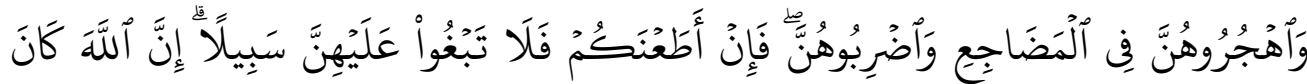
عَلِيَّا كِبِيرًا

Laki-laki (suami) itu pelindung bagi perempuan (istri), karena Allah telah melebihkan sebagian mereka (laki-laki) atas sebagian yang lain (perempuan), dan karena mereka (laki-laki) telah memberikan nafkah dan hartanya. Maka perempuan-perempuan yang shaleh, adalah mereka yang taat (kepada Allah) dan menjaga diri ketika (suaminya) tidak ada, karena Allah telah menjaga (mereka). Perempuan-perempuan yang kamu khawatirkan akan nusyuz hendaklah kamu beri nasihat kepada mereka, tinggalkanlah mereka di tempat tidur (pisah ranjang), dan (kalau perlu) pukullah mereka. Tapi jika mereka menaatimu, maka janganlah kamu mencari-cari alasan untuk menyusahkannya. Sungguh Allah Mahatinggi, Mahabesar. (Q.S. An-Nisa, 4: 34)

Terlihat jelas bahwa laki-laki adalah pelindung bagi wanita. Sudah menjadi kewajiban bahwa suami harus melindungi istrinya. Laki-laki (suami) diberikan kelebihan yang beragam bila dibandingkan dengan wanita. Ia menafkahi istrinya sebagai bentuk tanggungjawab dan menjalankan kewajibannya sebagai seorang suami. Memberikan kehidupan yang layak kepada istri merupakan sebuah tugas yang Allah perintahkan. 
Akan tetapi, sebagai seorang istri yang shalehah ia harus bisa menjaga diri ketika suami tidak ada di rumah. Artinya seorang istri tidak boleh melakukan hal-hal yang dilarang syari'at agama selama suami mencari nafkah. Ia harus tetap menjaga harga diri dan nama baiknya terutama harga diri dan nama baik suaminya.

Dari ayat tersebut di atas menerangkan bahwa suami berkewajiban menanggung semua kebutuhan istri. kebutuhan di sini adalah kebutuhan rumah tangga yang dibutuhkan sehari-hari, seperti makanan, pakaian, dan perabotan rumah. Bahakan kebutuhan pribadi istri seperti alat-alat kecantikan pun harus terpenuhi oleh suami.

Menurut pendapat Kyai Achmad Saepulloh, pada dasarnya tidak ada yang mewajibkan istri menafkahi suaminya dalam keadaan apapun. Seperti dalam surat An-Nisa ayat 34 di atas, tidak disebutkan bahwa seorang istri juga wajib memberikan nafkah kepada suami. Namun apabila sebuah kondisi dan keadaan yang memaksa istri harus bekerja mencari nafkah, maka boleh-boleh saja istri bekerja untuk suami dan keluarga. Apalagi jika suami memang tidak mampu lagi menafkahi dikarenakan sakit. Namun bukan menjadi keharusan juga istri bekerja meskipun suami dalam keadaan sakit sekalipun, apalagi karena suami yang menganggur. Ia mempunyai pilihan jika menghadapi kenyataan tersebut. Pertama ia boleh pasakh nikah jika dirasa keadaan tersebut menimbulkan madharat, dan yang kedua ia tetap menerima keadaan suami yang tidak menafkahi dengan sabar daripada harus berpisah dengan suami. Maka ia boleh saja menggantikan suami untuk mencari nafkah. Semua itu tergantung pilihan dan keinginan istri itu sendiri.

3) Ustad Ida Rusda

Pendapat lain juga dikemukakan oleh Ustad Ida Rusda. Sebagai pemimpin dalam rumah tangga yang memiliki tanggungjawab untuk menafkahi, suami harus berusaha untuk mendapatkan penghasilan demi memenuhi kebutuhan keluarga. Namun bukan berarti suami harus dibebankan dengan tuntutan untuk memperoleh penghasilan yang lebih dari kemampuannya. Seperti Firman Allah dalam surat At-Talaq ayat 7:

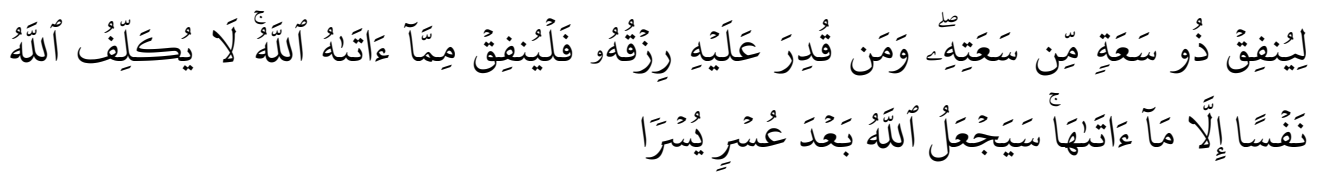

Hendaklah orang yang mampu memberi nafkah menurut kemampuannya. Dan orang yang disempitkan rezekinya hendaklah memberi nafkah dari harta yang diberikan Allah kepadanya. Allah tidak memikulkan beban kepada seseorang melainkan (sekedar) apa yang Allah berikan kepadanya. Allah kelak akan memberikan kelapangan sesudah kesempitan. (Q.S At-Talaq, 65: 7) (Depag RI, 1999: 946) 
Dalam ayat tersebut menjelaskan bahwa nafkah yang diberikan harus disesuaikan dengan kemampuan suami itu sendiri, jangan sampai melebih-lebihkan bahkan memaksakan diri. Istri juga tidak boleh menuntut lebih dari kemampuan suami, terima apapun dan berapa pun rezeki yang telah suami dapatkan. Namun, apabila ia (suami) memiliki kesempitan dalam menghasilkan rezeki, maka berikanlah apa yang suami dapatkan kepada istrinya.

Kata "orang" dalam surat At-Talaq di atas bukan hanya suami yang memberikan nafkah kepada istri saja, akan tetapi seseorang yang mampu memberikan rezeki dan nafkahnya kepada keluarga, kerabat, bahkan hewan peliharaan seperti yang telah Ustad Ida katakan sebelumnya.

Dalam hal ini, berikanlah nafkah sesuai dengan jumlah rezeki yang dihasilkan tanpa harus menyusahkan diri sendiri. Sebab Allah tidak akan memberikan beban melebihi batas kemampuan umat-Nya. Jika orang tersebut mampu menjalankan kehidupan dalam kesempitan dan kesulitannya, maka kelak Allah akan memberikan kelapangan kepadanya.

\section{KESIMPULAN}

Berdasarkan penjelasan di atas, begitu wajibnya seorang suami menafkahi istrinya. Apapun keadaannya, berapapun hasil yang didapatkan suami tetap berkewajiban untuk memberikan nafkah kepada istrinya. Akan salah jika suami membiarkan istri yang menafkahi dirinya, apalagi dengan alasan suami malas untuk bekerja. Meskipun istri diperbolehkan bekerja berdasarkan keinginannya sendiri, tetapi yang jelas pemikul kewajiban menafkahi adalah suami.

\section{DAFTAR PUSTAKA}

Abdurrahman, Dudung. (2003). Pengantar Metode Penelitian. Kurnia Alam: Yogyakarta

Al-Asqalani, Ibnu Hajar. (2014). Terjemah Bulugh Al-Maram. Pustaka Nuun:

Semarang

Al-Hafid bin Hajar Al-Asqalani. Bulugh Al-Maram

Amirin, M. Tatang. (1995). Menyusun Rencana Penelitian. PT Raja Grafindo: Jakarta 
Basyir, Ahmad Azhar. (1999). Hukum Perkawinan Islam. UII Press: Yogyakarta

Departemen Agama. (1991). Kompilasi Hukum Islam. Humaniora Utama Press: Bandung

Hasan, Muflihun. Kisah 25 Nabi dan Rasul. CV. Ita: Surakarta

Haya. (2008). Ensiklopedi Wanita Muslimah. PT Darul Falah: Jakarta

Jamaa, Laa. dkk. (2008). Hukum Islam dan Undang-undang Anti Kekerasan Dalam Rumah Tangga. PT Bina Ilmu: Surabaya

Moleong, Lexi J. (2000). Metode Penelitian Kualitatif. Cetakan Ke Sebelas. Remaja Rosda Karya: Bandung

Mujib, Abdul. (1996). Kaidah-kaidah Ilmu Fiqih. Kalam Mulya : Jakarta Pusat

Pusat Bahasa. (2001). Kamus Besar Bahasa Indonesia. Balai Pustaka : Jakarta

Rasjid, Sulaiman. (2014). Fiqih Islam. Cetakan Ke-65. Sinar Baru Algensindo: Bandung

Sabiq, Sayyid. (1987). Fiqih Sunnah 14. PT Alma'arif: Bandung . (2008). Fiqih Sunnah Jilid 3. Cakrawala Publishing : Jakarta

Subekti, dkk. (1996). Kitab Undang-undang Hukum Perdata. Pradaya Paramita: Jakarta

Syeikh Muhammad. 'Uqud Al-Lujain

Yunus, Mahmud. (2010). Kamus Arab Indonesia. PT Mahmud Yunus Wa Dzurriyyah: Jakarta. 